\title{
Modeling and remote sensing of an indirect Pyro-Cb formation and biomass transport from Portugal wildfires towards Europe
}

\author{
Stavros Solomos $^{\mathrm{a}, *}$, A. Gialitaki ${ }^{\mathrm{a}}$, E. Marinou ${ }^{\mathrm{b}, \mathrm{a}}$, E. Proestakis ${ }^{\mathrm{a}}$, V. Amiridis ${ }^{\mathrm{a}}, \mathrm{H}$. Baars $^{\mathrm{c}}$, \\ M. Komppula ${ }^{\mathrm{d}}$, A. Ansmann ${ }^{\mathrm{c}}$

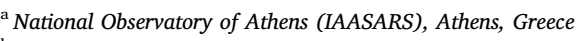 \\ ${ }^{\mathrm{b}}$ Institute of Atmospheric Physics, German Aerospace Center (DLR), Oberpfaffenhofen, Germany \\ ${ }^{\mathrm{c}}$ Leibniz Institute for Tropospheric Research (TROPOS), Leipzig, Germany \\ ${ }^{\mathrm{d}}$ Finnish Meteorological Institute, Kuopio, Finland
}

\section{A R T I C L E I N F O}

\section{Keywords:}

Pyro-Cb

Biomass

Wildfire

\begin{abstract}
A B S T R A C T
A unique event of long-range transport of biomass burning aerosol over Europe is detected by EARLINET and CALIPSO during 18-23 June 2017. The origin of these layers was a series of deadly wildfires that started in Portugal on 17 June 2017. This is the first time that smoke layers originating from West Europe are found at such long distances reaching up to Crete. In this work we use remote sensing (Polly ${ }^{\mathrm{XT}}$ lidars, CALIPSO, MSG) and modeling synergies (FLEXPART-WRF) to describe the properties of the emitted smoke and its atmospheric transport. Emission fluxes and injection heights are parameterized based on the hourly MSG-SEVIRI detections of Fire Radiative Power (FRP). Atmospheric dynamics is the main cause for this event; smoke particles are uplifted to the upper tropospheric layers due to convective activity over the Iberian Peninsula and this indirect pyro- $\mathrm{Cb}$ formation favors their transport to very long distances westward.
\end{abstract}

\section{Introduction}

During 20 to 23 of June 2017 a high layer of smoke was evident over several lidar stations in Europe. The origin is believed to be a series of deadly wildfires that erupted across central Portugal in the afternoon of June 17th' 2017. Similar smoke layers are often detected by satellites and lidar stations in Southeast Europe and Greece originating mostly from local fires in the Balkans or from the agricultural fires in Kazakhstan and the Black Sea (Balis et al., 2003; Amiridis et al., 2009; Giannakaki et al., 2010; Solomos et al., 2015). However, biomass burning particles (BBA) from West Europe and more specifically from Portugal have never been identified at such long distances.

A key component that determines the distance of smoke transport is the initial plume rise and the relative stability conditions during the emission stage. Positive (upward) buoyancy of the air masses containing the BBA particles allows the elevation of the plumes above the local planetary boundary layer (PBL) into the free troposphere and the relatively laminar flow at these heights favors their long range transport. Otherwise, smoke remains trapped inside the PBL and the plumes are quickly deposited and diluted due to near surface turbulence. The increased heat release from severe fires can lead to such vertical motions and to the development of a biomass convective cloud i.e. a
Pyrocumulonimbus cloud (Pyro-Cb) (Fromm et al., 2003, 2010; Rosenfeld et al., 2007) Pyro-Cbs are deep convective clouds driven by large scale fires. Due to the intense surface heating, the strong PyroCb updrafts can even penetrate the lower stratosphere. However, such positive buoyancy can also be achieved by convective motions during thunderstorm generation. Since light strike is a very frequent cause of wildfire ignition, convective activity and wildfires often coexist. In such a case, biomass smoke can be injected inside the updraft convective cells resulting in rigorous plume rise and uptake of the smoke layers by the free tropospheric flow. A similar case (at a much smaller scale) has been analyzed by Solomos et al. (2015) for an event combining biomass smoke transport and convective activity near Thessaloniki in Greece. In that case, the interchange between land and sea PBL as well as the development of convective storms along the plume path were the main reasons that resulted in elevated smoke layers up to $3 \mathrm{~km}$ in the atmosphere. Such smoke clouds cannot be classified as pyro- $\mathrm{Cb}$, since the main cause of the uplift is the local meteorology and not the energy released by the fire itself. However, since these convective processes are similarly effective in injecting smoke towards higher tropospheric layers, these can be considered as indirect pyro-Cb formations.

BBA have a significant effect on planetary radiative budget through scattering and absorption of solar and terrestrial radiation and the

\footnotetext{
* Corresponding author.

E-mail address: stavros@noa.gr (S. Solomos).
} 
interaction of BBA with incident radiation depends on a variety of parameters, such as the age of the smoke plume and the amount of black or brown carbon contained in the particles (e.g. Amiridis et al., 2009). Due to their abrupt ascent, Pyro-Cbs can even penetrate the tropopause and release large amount of BBA particles into the lower stratosphere. The abundance of aerosol particles acting as cloud condensation nuclei (CCN) and ice nuclei (IN) favors the formation of small ice crystals or super-cooled water droplets. Once reaching to unsaturated atmospheric layers these ice or super-cooled condensates evaporate and release the smoke particles back to the atmosphere. In these elevated atmospheric layers the interaction of BBA with other particle types is limited and thus their lifetime is extended. As a result, they can remain in the upper troposphere/lower stratosphere region even for months. The climatic effect in this case can be very difficult to quantify.

In the present work we examine the possible reasons that led to this unusual biomass smoke transport from Portugal towards Greece in June 2017. The analysis is based on Cloud-Aerosol Lidar and Infrared Pathfinder Satellite Observation (CALIPSO), the Spinning Enhanced Visible and Infrared Imager (SEVIRI) and Visible Infrared Imaging Radiometer Suite (https://earthdata.nasa.gov/earth-observation-data/ near-real-time/download-nrt-data/viirs-nrtVIIRS) satellite retrievals, FLEXPART-WRF dispersion simulations and lidar observations from the European Aerosol Research Lidar Network (EARLINET). The EARLINET stations used in this study are located in Leipzig, Germany (51.35 N, 12.43 E, 90 a.s.1.) and Finokalia Crete ( 35.34 N, 25.67 E, 238 a.s.l.). The stations are equipped with Raman-polarization lidars monitoring, on a 24-h basis, the vertical distribution of tropospheric aerosols and their optical properties (Mattis et al., 2004; Pappalardo et al., 2010).

The study is organized in four sections: In Section 1 we present the evolution of the wildfire event based on satellite retrievals and the methodological steps used in our analysis. In Section 2 the dispersion of smoke is simulated with FLEXPART-WRF and the results are compared with the corresponding detections at the EARLINET stations and CALIPSO overpasses to investigate the driving forces behind this event. In Section 3 we present the microphysical and optical properties of the elevated BBA particles based on Polly ${ }^{\mathrm{XT}}$ lidar retrievals at the stations of Leipzig and Finokalia. Section 4 focuses on the concluding remarks regarding the analysis of this unusual event.

\section{Event description and satellite evidence}

On June 17, 2017 a series of deadly wildfires spread across the mountainous areas of Pedrógão Grande-a municipality in central Portugal located about $160 \mathrm{~km}$ northeast of Lisbon (Fig. 1). During the days preceding the fires, Portugal experienced an intense heat wave

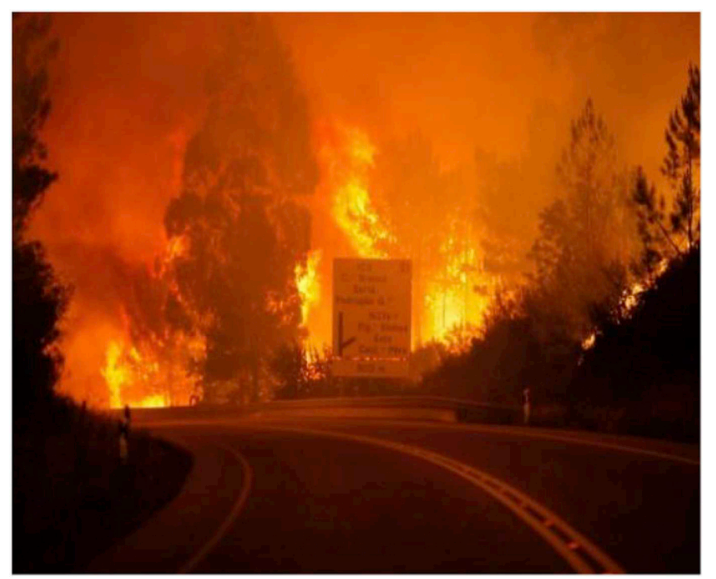

Fig. 1. Flames engulf a highway in Pedrogao Grande (https://www.bbc.com/ news/world-europe-40316934). with temperatures exceeding $40^{\circ} \mathrm{C}$, which increased the fire risk at the affected areas.

A seen in Fig. 2, the fire burning at Pedrogao Grande is captured by the VIIRS on board the SuomiNPP satellite (Fig. 2a and b) and also by the Moderate Resolution Imaging Spectroradiometer (MODIS) on NASA's Terra and Aqua satellites (Figure c). The majority of the fires started during the night of the 17th to the 18th of June and their location is evident in Fig. 2. Biomass smoke dispersion is also evident in Fig. 2c as gray plumes drifting out of the fires region towards the north and also towards Spain.

\subsection{Model description}

For the description of the event, we use the FireHub smoke dispersion system as described in Solomos et al. (2015). The major components of this application are the offline coupled atmospheric and dispersion model FLEXPART-WRF (Brioude et al., 2013) and the $15 \mathrm{~min}$ MSG-SEVIRI observations of fire hot spots. WRF_ARW (Skamarock et al., 2008) is set up at $12 \times 12 \mathrm{~km}$ grid space and 31 vertical levels and provides hourly outputs to drive the FLEXPART dispersion simulations. Initial and boundary fields are from the National Centers for Environmental Prediction (NCEP) final analysis dataset (FNL) at $1^{\circ} \times 1^{\circ}$ resolution. Daily updated Sea Surface Temperature (SST) is taken from the NCEP $1^{\circ} \times 1^{\circ}$ analysis. SEVIRI hot-spots and FRP are obtained from the WFABBA platform (http://wfabba.ssec.wisc.edu/index.html, Zhang et al., 2012).

Smoke emission rates are calculated with Eq. (1) directly from the FRP observations following Ichoku and Kaufman (2005), where $\mathrm{E}$ is the emission rate and $\mathrm{C}$ is a constant tuning parameter of $0.026 \mathrm{~kg} \mathrm{MJ}-1$ as derived from the top-down smoke aerosol emission coefficient database (http://feer.gsfc.nasa.gov/) developed by Ichoku and Ellison (2014).

$\mathrm{E}\left(\mathrm{kg} \mathrm{s}^{-1}\right)=\mathrm{C}\left(\mathrm{kg} \mathrm{MJ}^{-1}\right) \times \mathrm{FRP}\left(\mathrm{MJ} \mathrm{s}^{-1}\right)$

For the computation of injection heights, we adopt a simple expression (Eq. (2)) again based solely on FRP values. This approximation is computationally efficient and yields reasonable values for mid-latitude fires (Amiridis et al., 2010) allowing strong fires with high FRP to inject smoke above PBL into the free troposphere. The dispersion runs are set up in sequential hourly warm start cycles. The emissions are updated every hour from SEVIRI detections and each simulation is initialized with the smoke from the previous run (warm start). This approach provides an efficient way to remove small fires and false alarms from the simulation and at the same time to enhance the emissions from the actual burning fires. Only Portugal hot spots are used in the simulations in order to ensure that all dispersed particles have the same origin.

INJ_HGT $(\mathrm{m})=10^{\left(0.39 \times \log _{10}(\mathrm{FRP})+2\right)}$

For each hourly run during the warm-cycle sequence we use 1000 tracer particles per hot spot and the particles are assumed to be organic carbon. The accurate representation of size distributions for the emitted particles is a very complex task involving the effects of flaming and smoldering fire types, fuel properties, ambient conditions as well as the time evolution of the above processes (Hosseini et al., 2010). Since most of the smoke transport takes place in a relatively moist atmosphere we assume a rather coarse mass median diameter of $0.2 \mu \mathrm{m}$ and a standard deviation $\sigma=0.2 \mu \mathrm{m}$ as a simple approach to account for the effects of atmospheric aging and secondary organic aerosol formation (Vakkari et al., 2018). Dry and wet deposition processes are enabled in these runs. Sensitivity model runs (not shown) indicated a very limited response of the simulations towards the particle properties and most of the variation in the transported plumes comes from the meteorological forcing. 

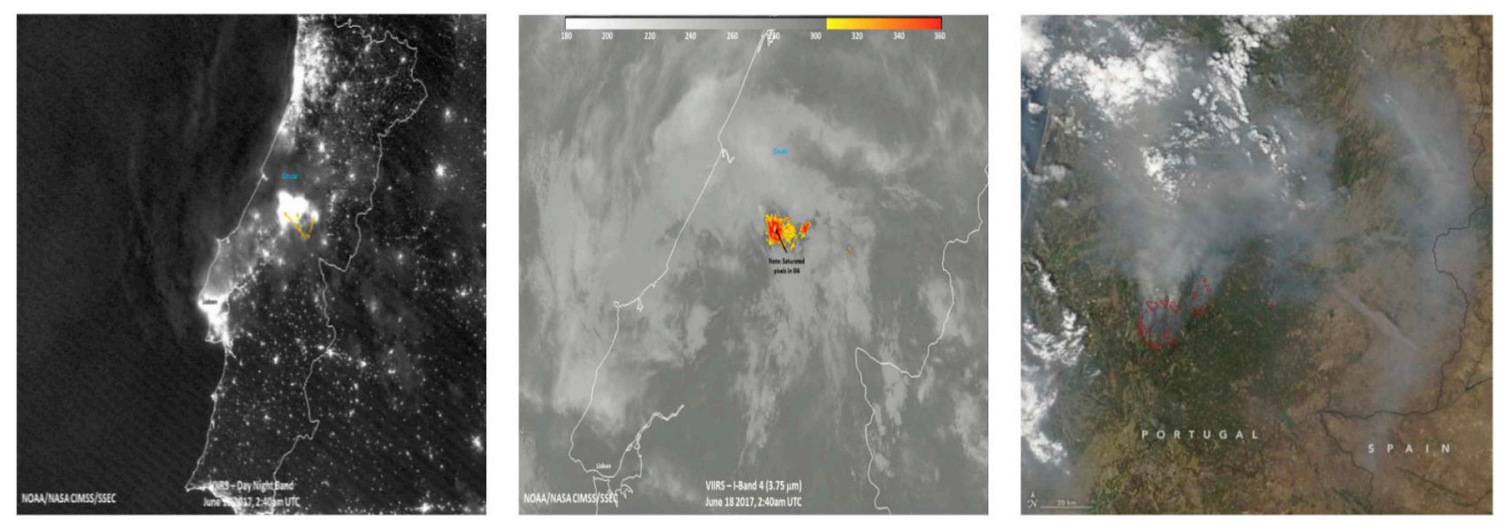

Fig. 2. a) VIIRS DNB Visible Imaginary $(0.70 \mu \mathrm{m})$ and b) VIIRS I band $(3.75 \mu \mathrm{m})$ both taken on June 18th, 2:40UTC, c) MODIS true color image of active fires hotspots and smoke on June 18th,11:10UTC. (For interpretation of the references to color in this figure legend, the reader is referred to the Web version of this article.)

\subsection{Description of the lidar system}

We make use of EARLINET Polly ${ }^{\mathrm{XT}}$ multi-wavelength Raman/polarization lidars (Engelmann et al., 2016; Baars et al., 2016) measurements in Leipzig and Finokalia, in order to estimate the optical properties and mass concentration of the elevated smoke plumes. Quicklooks of all Polly ${ }^{\mathrm{XT}}$ measurements can be found on the web page of PollyNet (http://polly.tropos.de). Polly ${ }^{\mathrm{XT}}$ operates using a Nd:YAG laser emitting linearly highly polarized light at 1064, 532 and $355 \mathrm{~nm}$. A Newtonian telescope with a $300 \mathrm{~mm}$ diameter primary mirror is used to receive the light backscattered from aerosols and molecules in the atmosphere. The emitted laser beam enters the telescope 1 mrad field of view at about $600-800 \mathrm{~m}$ height above the ground. To conduct trustworthy measurements below this region Polly ${ }^{\mathrm{XT}}$ is also equipped with a near range receiver, with a $50 \mathrm{~mm}$ diameter mirror and $2.2 \mathrm{mrad}$ field of view, thus limiting the full overlap region between the laser beam and receiver field of view to about $100 \mathrm{~m}$ above the ground.

The received radiation is separated by wavelength and photons elastically (at 355, 532, $1064 \mathrm{~nm}$ ) and inelastically (at 387 and $607 \mathrm{~nm}$ ) backscattered in the atmosphere are measured using the photoncounting method. Data are acquired with a $7.5 \mathrm{~m}$ vertical resolution and averaged every $30 \mathrm{sec}$. In order to account for the presence of nonspherical particles, the co- and cross-polarized component (with respect to the emitted radiation) of the detected radiation, at 355 and $532 \mathrm{~nm}$ is used to calculate the linear particle depolarization ratio (PLDR). The backscatter (b) and extinction (a) coefficient profiles at 355 and $532 \mathrm{~nm}$ are derived using the Raman method proposed by Ansmann et al. (1992). For the backscatter coefficient profile at $1064 \mathrm{~nm}$, the lidar equation is solved using the Fernald-Klett method (Fernald, 1984; Klett, 1981) by assuming a constant value for the lidar ratio (S) (i.e the ratio of the extinction to backscatter). The Angstrom Exponent (AE), a parameter indicative of particles size is calculated for wavelengths 355/ 532 and 532/1064.

Using the Raman method to retrieve a and b coefficient results in overall errors of the order of $5-15 \%$ and $10-30 \%$ respectively. These uncertainties may lead up to $15-40 \%$ error in the S estimation, while errors range between 20 and $40 \%$ for AE and $5-10 \%$ for PLDR. A detailed description concerning the uncertainties related with the calculation of particle properties can be found in Baars et al. (2016), Freudenthaler et al. (2016) and Bravo-Aranda et al. (2016).

\subsection{Satellite data}

We use remote sensing data of the Fire Radiative Power (FRP) from SEVIRI to determine the distribution and strength of the fire hotspots and to quantify burned biomass for the region of Portugal. FRP (in MJ $\mathrm{s}^{-1}$ ) is a measure of the rate of radiant heat released per time unit by burning vegetation during the combustion process (Wooster et al., 2005) and provides useful information on fire dynamics and emissions. FRP is obtained at around $4 \mu \mathrm{m}$ in the shortwave infrared part of the spectrum and is linearly related to vegetation consumption (Wooster et al., 2005; Freeborn et al., 2008). The evolution of SEVIRI - FRP

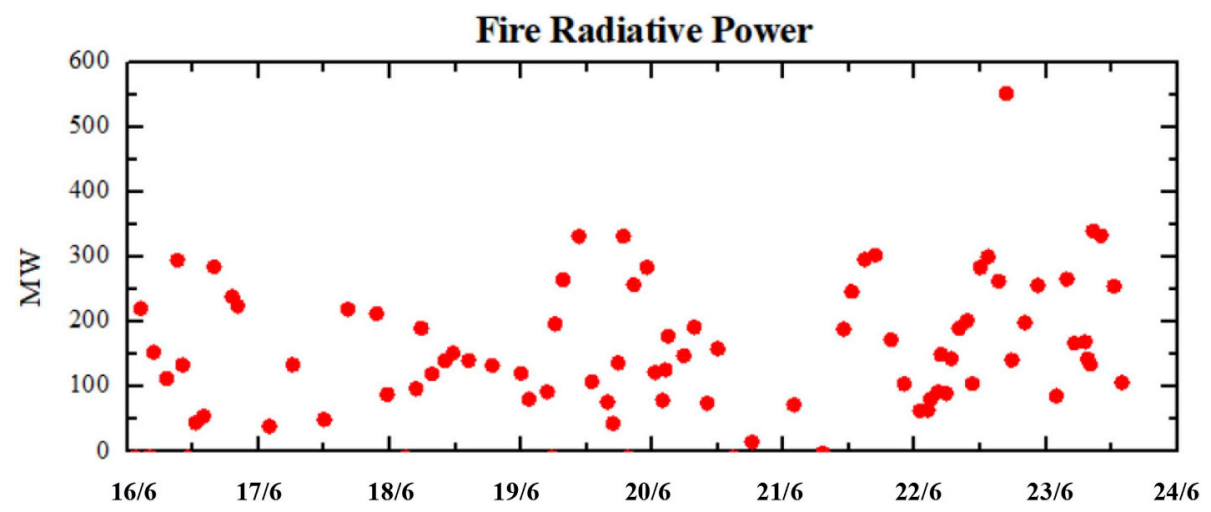

Fig. 3. Fire evolution in terms of FRP. The main phase of the fire took place during approximately $18-22$ June 2017. 


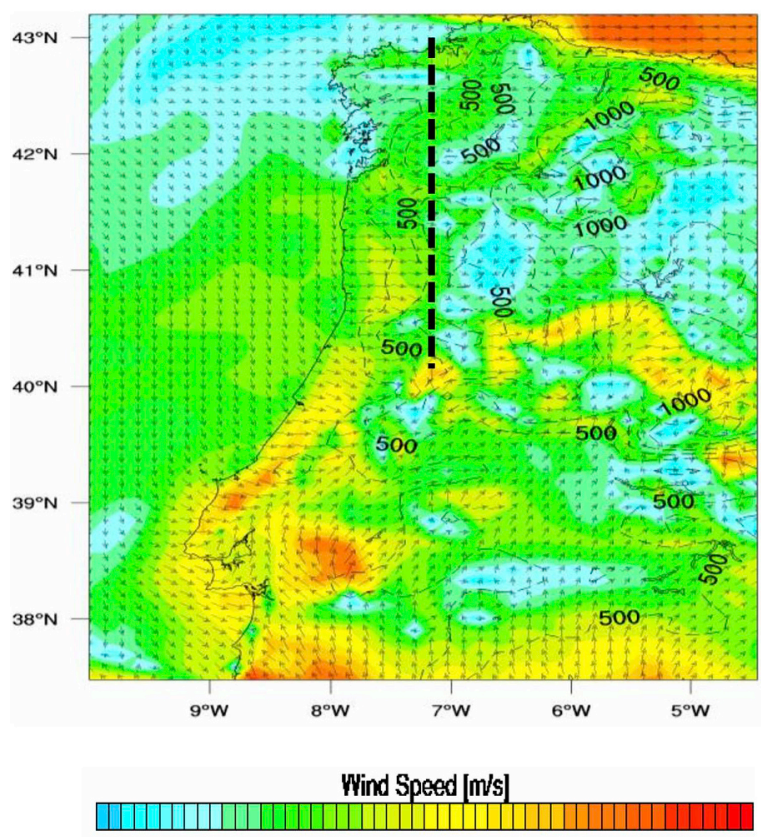

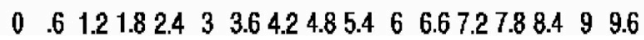

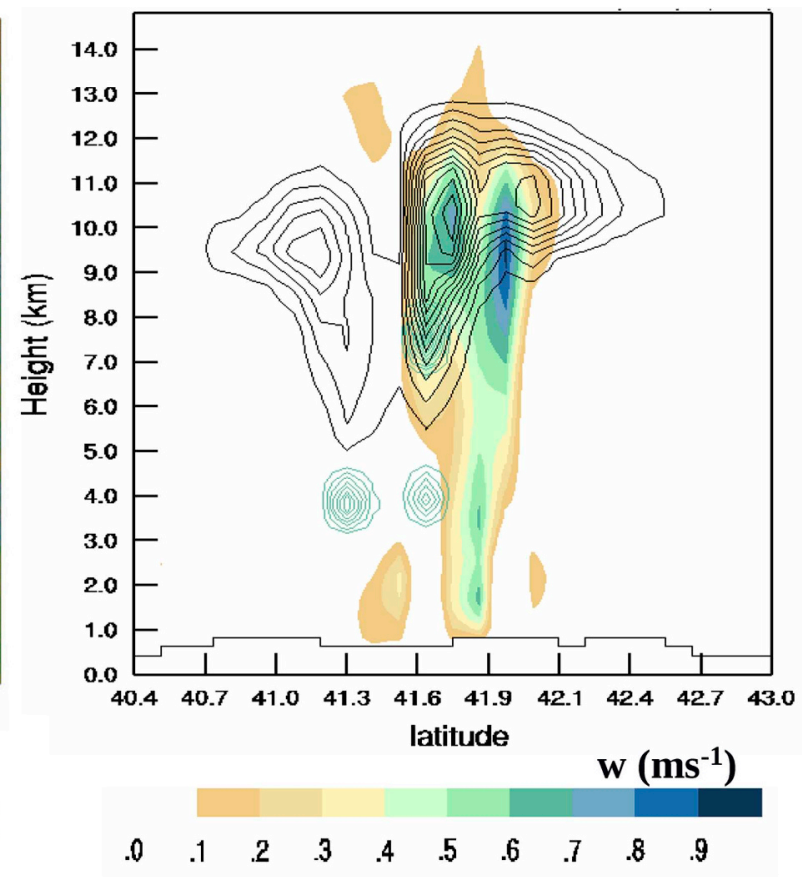

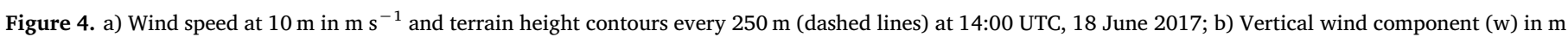
$\mathrm{s}^{-1}$ (color scale), liquid condensates mixing ratio (green contours every $0.01 \mathrm{~g} \mathrm{~kg}^{-1}$ ) and ice condensates mixing ratio (black contours every $0.01 \mathrm{~g} \mathrm{~kg}^{-1}$ ). The dashed black line in Fig. 4a shows the location of the Fig. $4 \mathrm{~b}$ cross-section.
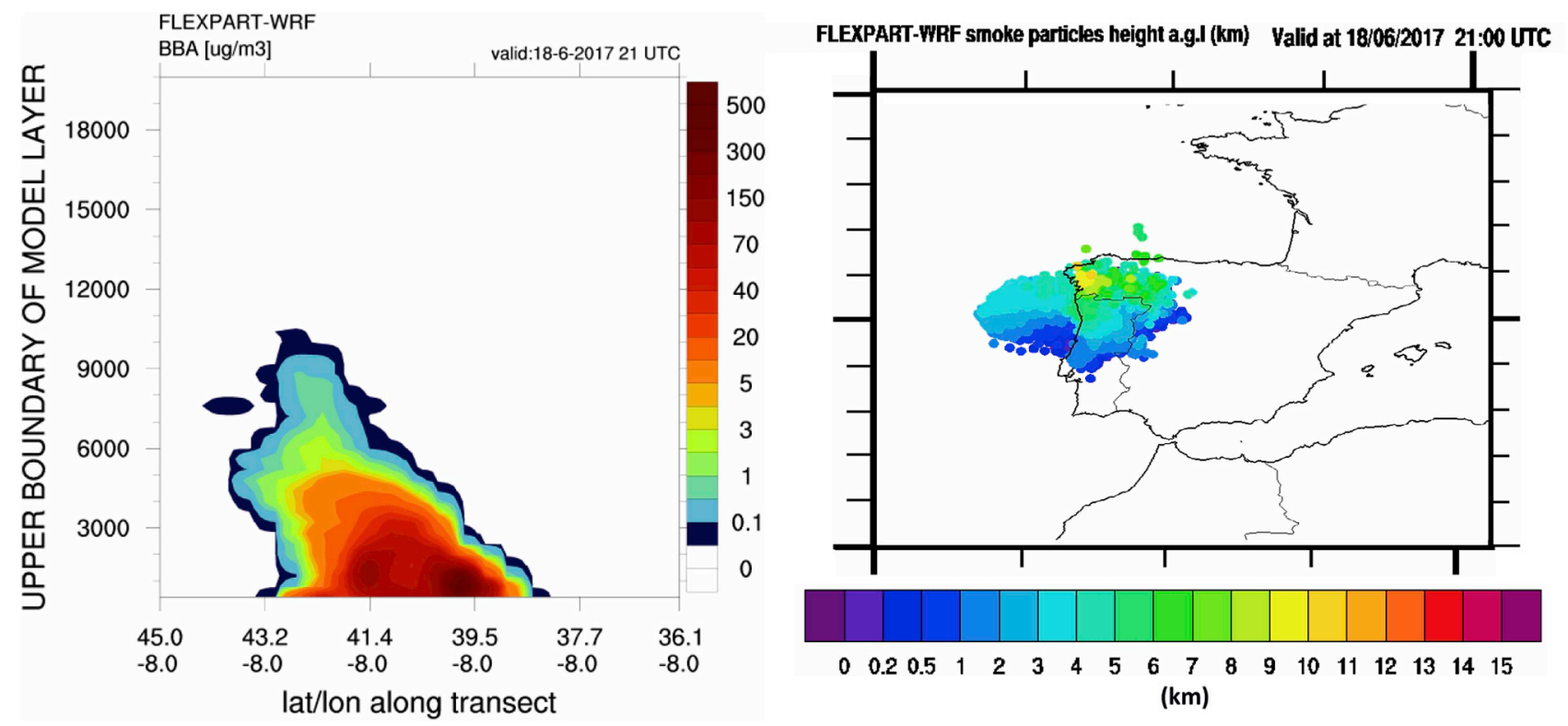

Fig. 5. a) Simulated particles heights (km) at 21:00 UTC, on 18 June 2017 (zoom from FLEXPART domain).

during the event is seen in Fig. 3. During the main stage of the firestorm (from 18th to 22nd of June) FRP reached approximately up to $350 \mathrm{MW}$.

CALIOP (Cloud-Aerosol Lidar with Orthogonal Polarization) measurements onboard the CALIPSO satellite (Winker et al., 2009; Omar et al., 2009), were used to track the transportation of biomass plumes over Europe. CALIOP emits linearly highly polarized light at 532 and $1064 \mathrm{~nm}$ and is also equipped with a polarization sensitive channel at $532 \mathrm{~nm}$ to retrieve particle depolarization. Three receiver channels are used measuring the backscattered signal at $1064 \mathrm{~nm}$ and the orthogonally polarized components at $532 \mathrm{~nm}$. The receiver telescope has a
$1 \mathrm{~m}$ diameter and a $130 \mu \mathrm{rad}$ field of view. High resolution profiles of attenuated backscatter at two wavelengths and volume linear depolarization, provided by CALIOP, are used to discriminate cloud phase as well as to account for the presence of non-spherical aerosols.

\section{Long range transport of smoke}

The combination of lower tropospheric convergence due to the sea breeze penetration from the Atlantic with high surface temperatures (up to $45^{\circ} \mathrm{C}$ ) on 18 June 2017 favored convection and storm generation 

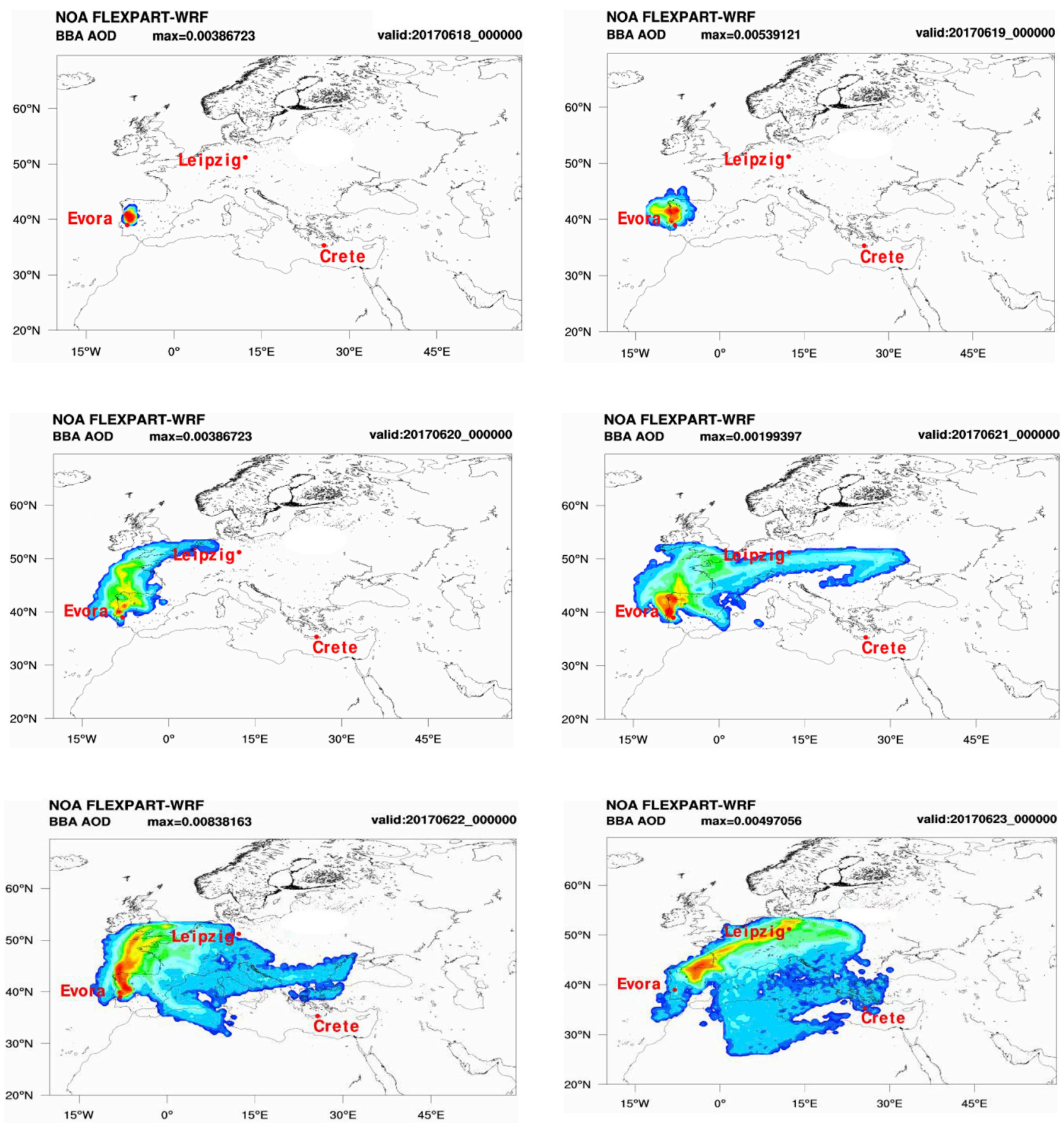

\section{TPM ( $\left.\mathrm{mg} \mathrm{m}^{-2}\right)$}

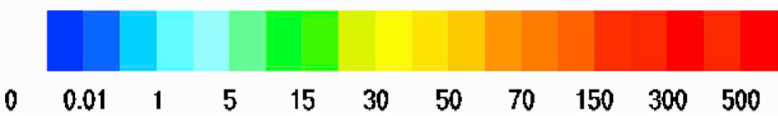

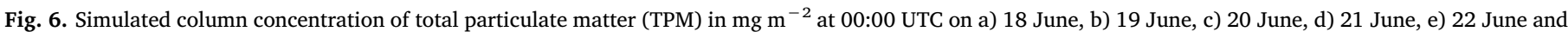

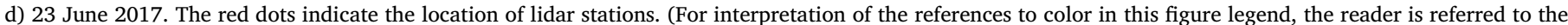
Web version of this article.)

at the north parts of Portugal. As seen in Fig. 4a, the sea breeze front is evident at 14:00 UTC by the WNW winds reaching up to $9 \mathrm{~m} \mathrm{~s}^{-1}$ along the Atlantic coastline. A series of convective cells were generated after the noon hours over the mountainous areas of North Portugal and as seen in Fig. 4b the updrafts reach up to $12 \mathrm{~km}$ accompanied by cloud formation. These updraft cells coexist with fire smoke and result in the uptake of BBA particles up to 10-12 km over North Portugal and Spain as seen in Fig. 5 at 21:00 UTC, 18 June 2017. These elevated layers are 


\section{Range corrected signal at $1064 \mathrm{~nm}$ PollyXT_FMI, Leipzig, Germany}

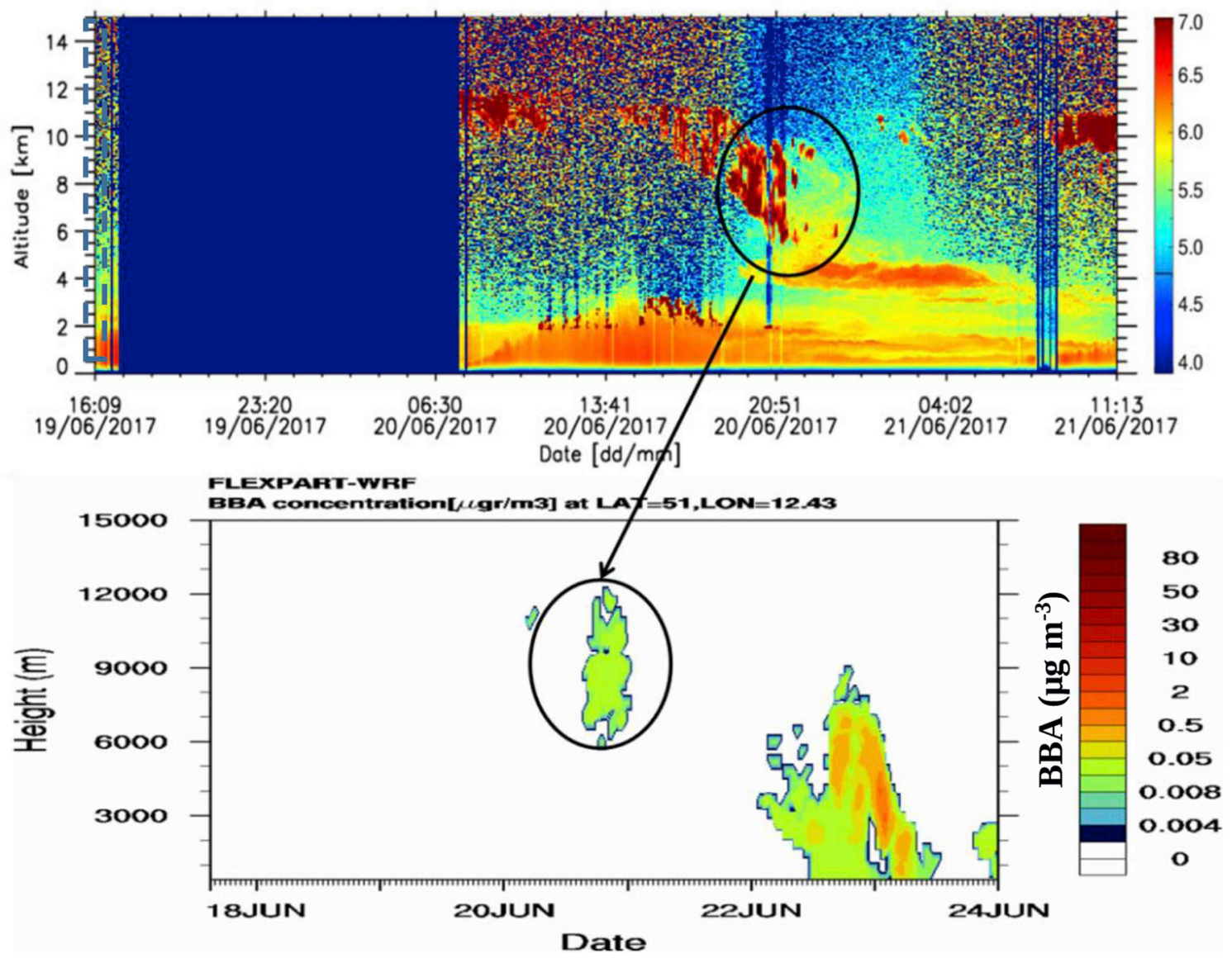

Fig. 7a. Polly ${ }^{\mathrm{XT}}$ range corrected signal at $1064 \mathrm{~nm}$ (up) for the period 19-21 June 2017 and modeled BBA concentration (down) over Leipzig, Germany, 18-24 June 2017.

afterwards eligible for the long range transport that is described in the following sections.

The dispersion simulation starts at 17 June 2017, 14:00 UTC when the first hot spots are detected by SEVIRI. By 18 June 00:00 UTC the simulated smoke is already spread over the north part of Portugal (Fig. 6a) and by 19 June 00:00 UTC the plumes extend further towards the Atlantic Ocean (Fig. 6b). Prevailing south winds at these areas force the smoke air masses towards the British Isles and North Europe on 20 June 00:00 UTC (Fig. 6c). This north flank of the plume travels further towards the East and at 00:00 UTC on 21 June, smoke is evident up to Poland and Russia (Fig. 6d). As these plumes travel south they dilute to very low but still detected concentrations in the model (less than $0.1 \mathrm{mg} \mathrm{m}^{-2}$ smoke-load) reaching Greece on 22 June 00:00 UTC (Fig. 6e). At this time a south plume flank is also evident travelling through Spain towards Tunis and Algeria. On 23 June 00:00 UTC the modeled particles eventually reach Crete, however at very low columnar concentrations (less than $0.01 \mathrm{mg} \mathrm{m}^{-2}$ ). The vertical structure of the layers is described in the following paragraphs.

\subsection{Vertical structure of the smoke layers}

Collocated lidar and model plots for the temporal evolution of smoke propagation above Central Europe (Leipzig-Germany) and South Europe (Finokalia-Crete) are used in this section to describe the vertical properties of the plumes (Fig. 7). As stated in Section 1.2, only Portugal fire emissions are input in the model and all simulated particles originate from that area. The smoke plume is detected over Leipzig on 20
June at about $6-10 \mathrm{~km}$ and reproduced also by the model (Fig. 7a), however at very low concentrations (less than $0.05 \mu \mathrm{g} \mathrm{m}^{-3}$ ). A denser smoke layer is simulated on 22 and 23 June which is also downward mixed towards the ground. Unfortunately, the Polly ${ }^{\mathrm{XT}}$ system of the Finnish Meteorological Institute (FMI), operating at Leipzig during these days, was not operational and no direct comparison is possible. The biomass smoke eventually reaches Greece on 22 June. A descending sequence of elevated layers is detected in Finokalia station starting at $11-12 \mathrm{~km}$ on 22 June and lowering down to $10 \mathrm{~km}$ on 23 June and to $6-9 \mathrm{~km}$ on 24 June. This situation is reproduced by the model in adequate agreement with the observations taking also into account the long range transport and the very low smoke concentrations (Fig. 7b). The first layer on 22 June is not simulated since the modeled smoke has not yet arrived in Finokalia (see also Fig. 6e). This implies either latency in smoke propagation or a different origin for that layer. The other two layers in 23 and 24 June are simulated at very low concentrations (less than $0.05 \mu \mathrm{g} \mathrm{m}^{-3}$ ).

\subsection{CALIPSO detections}

The smoke layers are also detected by CALIPSO overpasses during this period allowing the description of smoke transport at bigger scales. These plots are used for qualitative comparison with the corresponding model cross-sections. Fig. 8 shows the CALIPSO classification observations along with the collocated FLEXPART cross-sections and particle height plots. Satellite fields are compared to the closest hour output of the model. The smoke layers are initially transported towards the north 
Range corrected signal at $1064 \mathrm{~nm}$ PollyXT_NOA, Finokalia, Greece

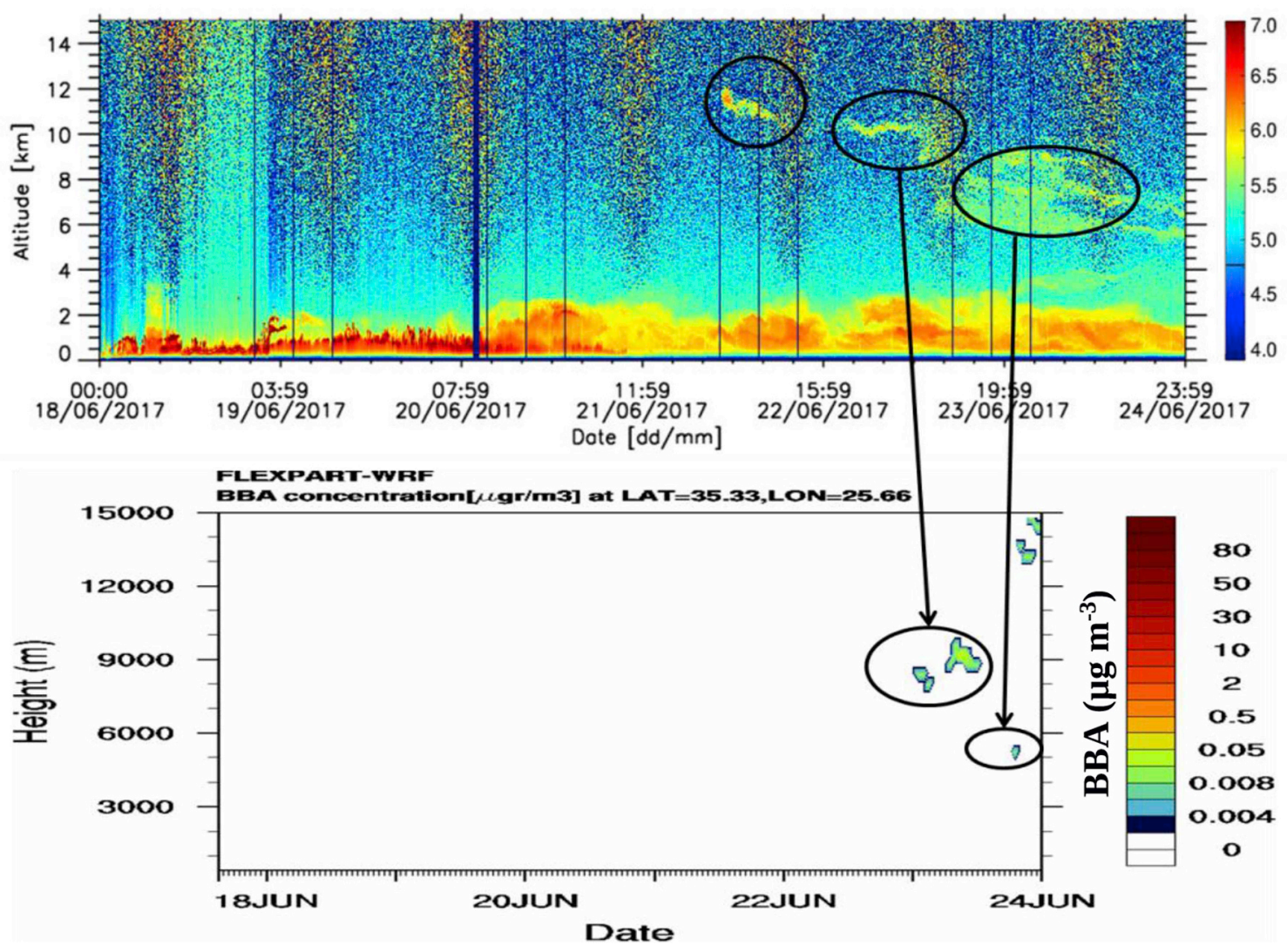

Fig. 7b. Polly ${ }^{\mathrm{XT}}$ range corrected signal at $1064 \mathrm{~nm}$ (up) and modeled BBA concentration down) over Finokalia Greece, $18-24$ June 2017.

as seen in Fig. 8aiii for 19 June, and also elevated to higher atmospheric layers up to $10 \mathrm{~km}$ due to the convective motions at this area as discussed also in Fig. 4. These layers are detected by CALIPSO between $43^{\circ} \mathrm{N}$ and $49^{\circ} \mathrm{N}$ and also simulated by the model (Fig. 8ai, 8ai).

The uplift at the early stage of the event is the key for the long range transport during the following days. On 20 June the elevated smoke layers have already reached the north parts of Germany and are detected by the 01:32-01:45 UTC CALIPSO overpass (Fig. 8bi). The model reproduces the smoke heights at $9-12 \mathrm{~km}$ (Fig. 8bii), however with latency in time. This latency is evident in Fig. 8biii where the dashed black line indicates the CALIPSO track and the red line shows the model cross-section. As seen in this figure the modeled plume has not yet arrived below the satellite overpass at 02:00 UTC, 20 June 2017 and it is actually located about $3.5^{\circ}$ east. As the smoke travels more towards south-east (Fig. 8ciii) it is again detected by CALIPSO over Ukraine and Romania at 00:36-00:50 UTC, 21 June 2017 collocated also with clouds at this area (Fig. 8ci). The detected (Fig. 8ci) and modeled smoke layers (Fig. 8cii) are in good accordance indicating the existence of Portugal fire smoke at $6-12 \mathrm{~km}$ at this area. Closer to the sources the modeled smoke is mostly spread towards north and northwest directions and mostly constrained below 5-6 km as seen in Fig. 8diii at 14:00 UTC, 21 June 2017. This is partially supported by the CALIPSO detection in Fig. 8di, where the aerosol detected north of Spain (north of $40^{\circ} \mathrm{N}$ ) is actually Portugal fire smoke and it is also simulated by the model at this area (Fig. 8dii). However, the dense smoke plume that is simulated below $3 \mathrm{~km}$ near Ireland (at $50.5^{\circ} \mathrm{N}$ in Fig. 8dii) is not detected by the satellite. It is possible that the model under-predicts aerosol deposition and dilution inside the PBL at these areas and thus over-predicts near surface transport. The aerosol detected by CALIPSO south of $40^{\circ} \mathrm{N}$ in Fig. 8di is desert dust, so this is not reproduced by the model.

\section{Smoke properties}

To quantify BBA mass concentration inside the elevated smoke layers, we make use of nighttime lidar measurements at $532 \mathrm{~nm}$ and collocated sunphotometric measurements from the Aerosol Robotic Network (AERONET; Holben et al., 1998) stations at Leipzig and Finokalia. As shown by Ansmann et al. (2011, 2012) we can apply equation (3) to calculate mass concentration (M) from the particle density $(\rho)$ and the combination of lidar/sunphotometer measurements.

$M=\rho\left(\frac{\nu}{\tau}\right) \cdot b \cdot S$

Where, $v / \tau$ (i.e. the volume to extinction conversion factor) is the ratio of columnar particle volume concentration to the aerosol optical thickness determined by AERONET measurements, $\mathrm{b}$ is the particle backscatter coefficient at $532 \mathrm{~nm}$ and $S$ is the lidar ratio at $532 \mathrm{~nm}$ a value characteristic of aerosol type. By integrating $M$ over the BBA layer limits we can estimate the aerosol mass. The corresponding values for BBA mass concentration are listed in Table 1. Uncertainties related with the retrieval of mass concentration with this methodology, are excessively discussed inAnsmann et al. (2011) and Tesche et al. (2009; $2011 \mathrm{a}, \mathrm{b})$. These are first of all related with the assumed value for $\mathrm{S}$ and the corresponding retrieval of backscatter coefficient from the elastic lidar signal and can be as large as $20-30 \%$. In the present study we made an attempt to minimize this error by using also the Raman lidar measurements available at Finokalia station. The resulting $S$ value $(70 \mathrm{sr}$ at $532 \mathrm{~nm}$ ) was used to calculate BBA mass concentration at both stations. This is described in detail in paragraph 3.1. Another source of error is the parameter $\mathrm{v} / \tau$, which is depends on the optical and physical properties of the particles, and may cause an error of the order of $15 \%$. 


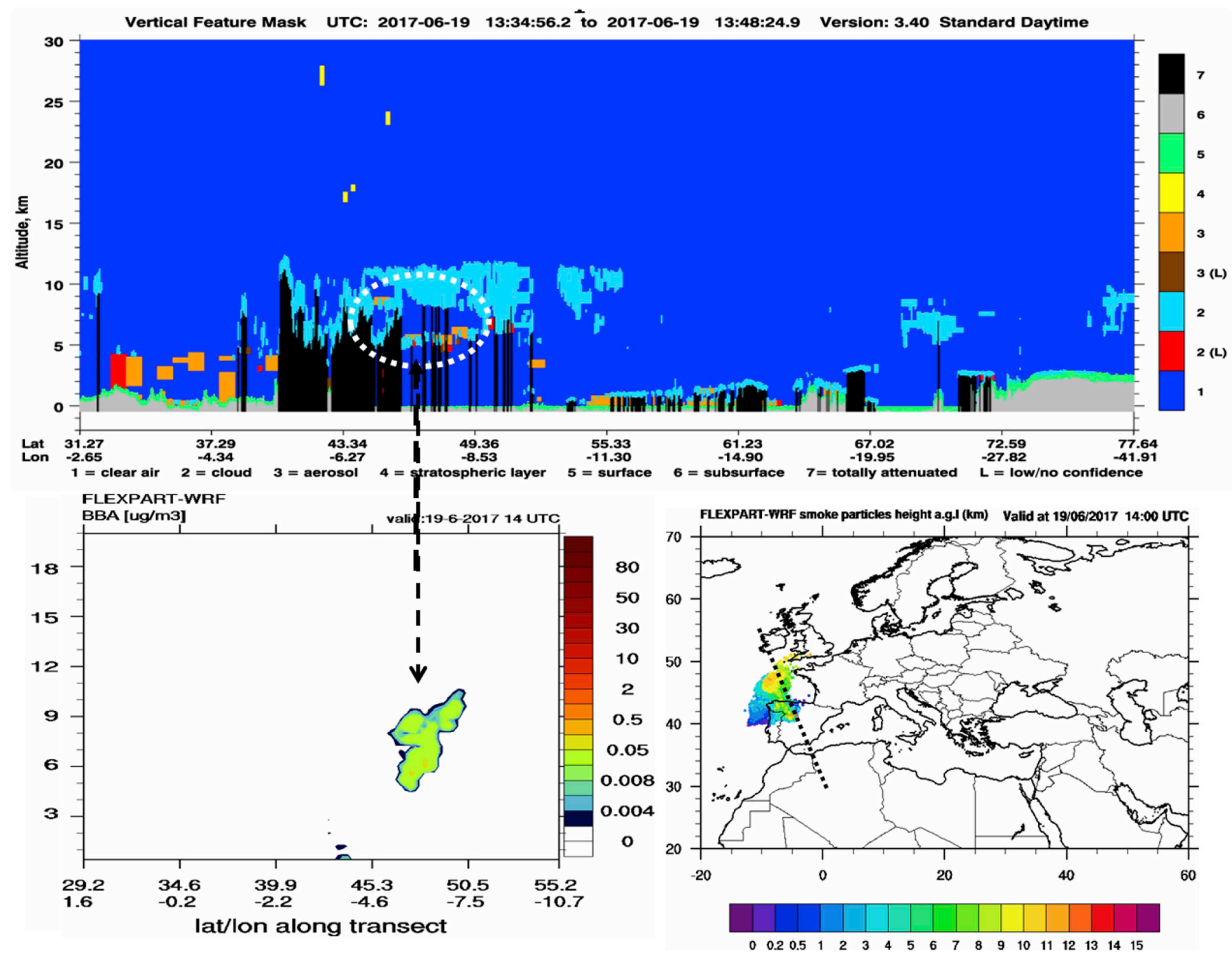

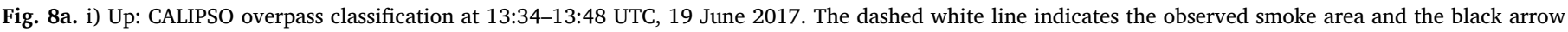

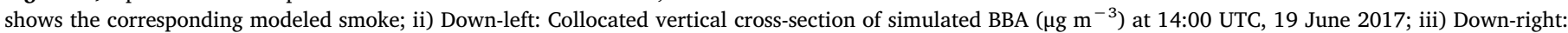
Simulated particles heights $(\mathrm{km})$ at 14:00 UTC, on 19 June 2017. The dashed line indicates the location of CALIPSO overpass.

However, this is especially true for large $(>15 \mu \mathrm{m})$, irregularly shaped particles (i. e. volcanic ash) which is not the cause here, since smoke particles tend to be rather small and more spherical. Finally, the particle mass density estimation causes an error of the order of $25 \%$. The overall error of the applied methodology is estimated to be $\sim 40 \%$ for the calculation of mass concentration.

\subsection{Methodology to minimize the retrieval error}

For the calculation of the aerosol backscatter coefficient, the Klett method was applied in all case studies, with an initial guess of 70sr for the lidar ratio at $532 \mathrm{~nm}$, which is a typical mean value for aged smoke particles. This initial lidar ratio selection is supported by the nighttime Raman measurements performed for the same air mass at the Finokalia station. For the calculation of the lidar ratio from these measurements, the Polly ${ }^{\mathrm{XT}}$ signal was first averaged at several time windows in order to define the signal to noise ratio (SNR) for the height range of the smoke plume (11.6-12.2 km). The maximum SNR appeared at the time window 00:15-01:45 UTC on 22/6. The SNR was found enough ( $>10$ ) for the independent determination of particle backscatter and extinction coefficient at $355 \mathrm{~nm}$. The value retrieved for the lidar ratio at $355 \mathrm{~nm}$ using the Raman method was found to be $65 \pm 10 \mathrm{sr}$. For the same case and time window, the signal at $532 \mathrm{~nm}$ was found to be too noisy to enable extinction and lidar ratio retrievals, thus only the particle backscatter coefficient has been retrieved at $532 \mathrm{~nm}$. In order to estimate a mean lidar ratio value at $532 \mathrm{~nm}$, we used the ratio of the lidar-collocated AERONET measurement of the aerosol optical depth (AOD) at $500 \mathrm{~nm}$ to the integrated backscatter coefficient retrieved with the Raman method. This method provided a mean columnar estimation of $72 \mathrm{sr}$ at $532 \mathrm{~nm}$. This value justifies our initial lidar ratio assumptions for aged BBA used in our retrieval of mass concentration. Furthermore, this value provides a reasonable wavelength dependence for the lidar ratio between 532 and 355, which is found to lie within the range of reported values for aged smoke (e.g. 1.15 as found by Müller et al., 2005, 2007).

\subsection{Central Europe - Leipzig station}

Observations carried out at the Leibniz Institute for Tropospheric Research (TROPOS) from June 19th to June 21st are seen in Fig. 7a. The range corrected signal at $1064 \mathrm{~nm}$ shows a dense BBA plume reaching Leipzig lidar station on June 20th around 21:00 UTC mixed with high clouds. During that period observations at Leipzig were conducted using the Polly 1v2 system of TROPOS (http://www.tropos. 


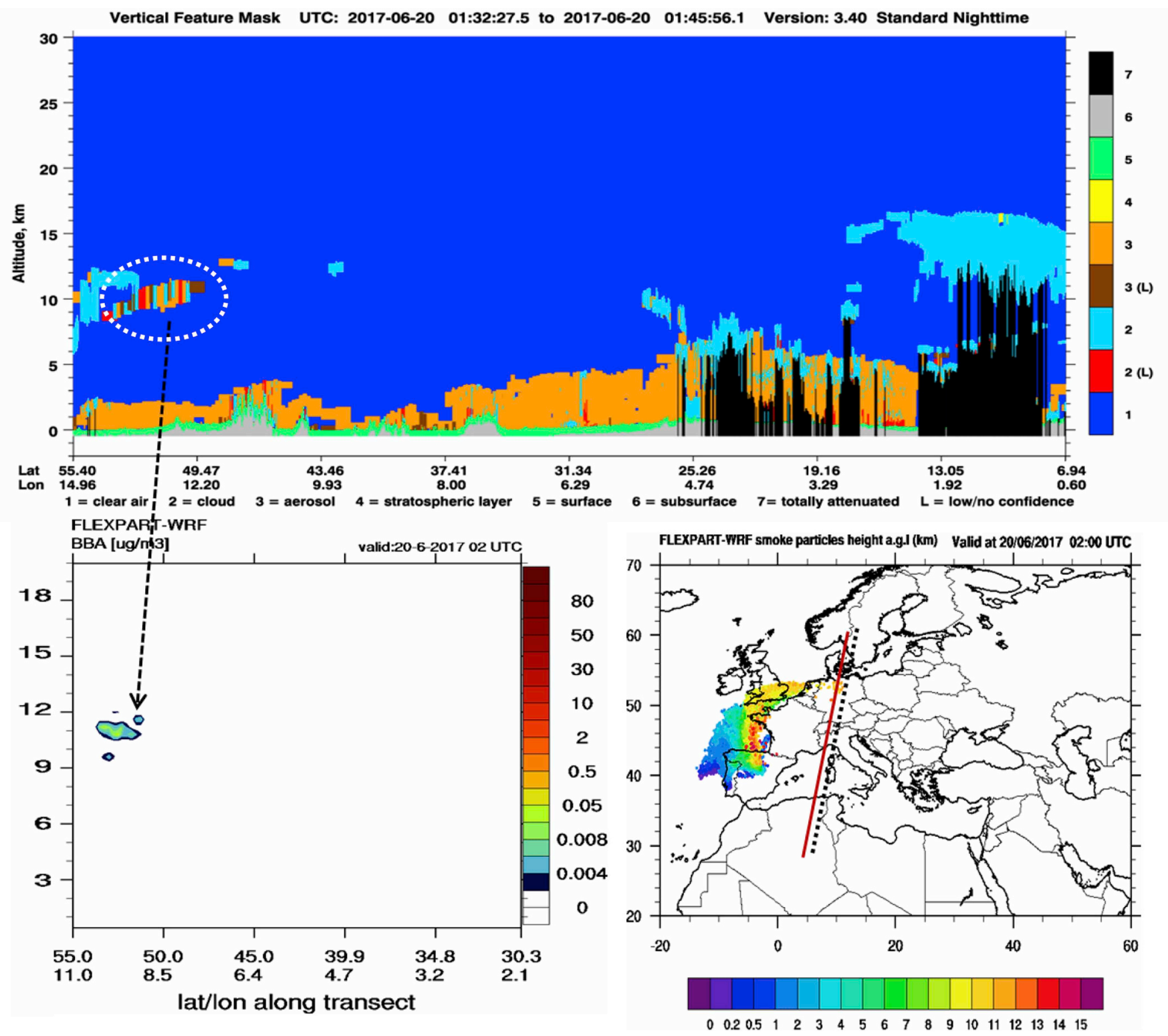

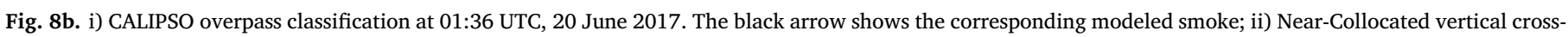

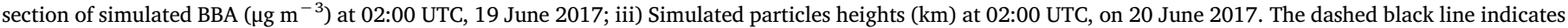

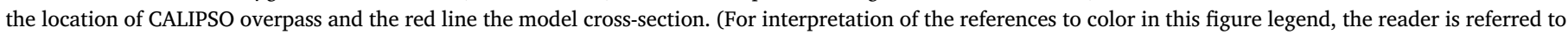
the Web version of this article.)

de/en/) and also the FMImulti-wavelength lidar system, the type of Polly ${ }^{\text {XT }}$ (http://en.ilmatieteenlaitos.fi/atmospheric-research-centre-ofeastern-finland). For relevance reasons of the current study, Polly XT FMI measurements were used. Due to limited available measurements only one retrieval of the aerosol optical properties was possible, on June 20th from 22:30 to 23:10 UTC, outlined in red in Fig. 7a. To make sure we avoided any cloud contamination in this retrieval, we carefully inspected the layer optical properties. High $\mathrm{AE}$ values ( $>1$ in comparison to almost 0 for cirrus clouds) in combination with low depolarization values $(<10 \%$ in comparison to $40-60 \%$ in case of cirrus clouds) advocate that this is indeed an elevated aerosol layer and not a cirrus cloud. Here, or the calculation of the aerosol backscatter coefficient at $532 \mathrm{~nm}$, the Klett method was applied, with $\mathrm{S}=70 \mathrm{sr}$ as explained in paragraph 3.1.). By applying the gradient method to the backscatter coefficient profiles (Flamant et al., 1997; Mattis et al., 2008) the elevated BBA layer limits are determined from approximately 4 to $10 \mathrm{~km}$. While for the upper part of the layer the values of $\mathrm{AE}$ at $(355 / 532) \mathrm{nm}$ and PLDR at $532 \mathrm{~nm}$ are approximately 1.5 and 0.01 respectively, for the lowermost part PLDR values are higher $(\sim 0.05)$ and $\mathrm{AE}$ shifts towards smaller values indicating a possible contamination of the BBA layer (not shown). For this reason, only the part of the plume corresponding to pure smoke is considered in Eq. (3) for the calculation of BBA mass concentration, i.e. from 5.5 to $10 \mathrm{~km}$. These limits are also in agreement with the modeled vertical distribution of the plume as seen in Fig. 7a. By integrating the particle extinction coefficient over layer limits, we calculate a BBA AOD at $532 \mathrm{~nm}$ of $0.24 \pm 0.01$ at Leipzig (Table 2). The corresponding maximum modeled concentrations are strongly underestimated $\left(22.2 \mu \mathrm{g} \mathrm{m}^{-3}\right.$ versus $1.13 \mu \mathrm{g} \mathrm{m}^{-3}$ ) implying a quicker decay of the smoke plume in the simulation.

\subsection{South Europe - Finokalia station}

The Polly ${ }^{\mathrm{XT}}$ multi-wavelength Raman/polarization lidar operated remotely by the National Observatory of Athens (NOA) at Finokalia Observatory in Crete, is used to calculate the optical properties and 


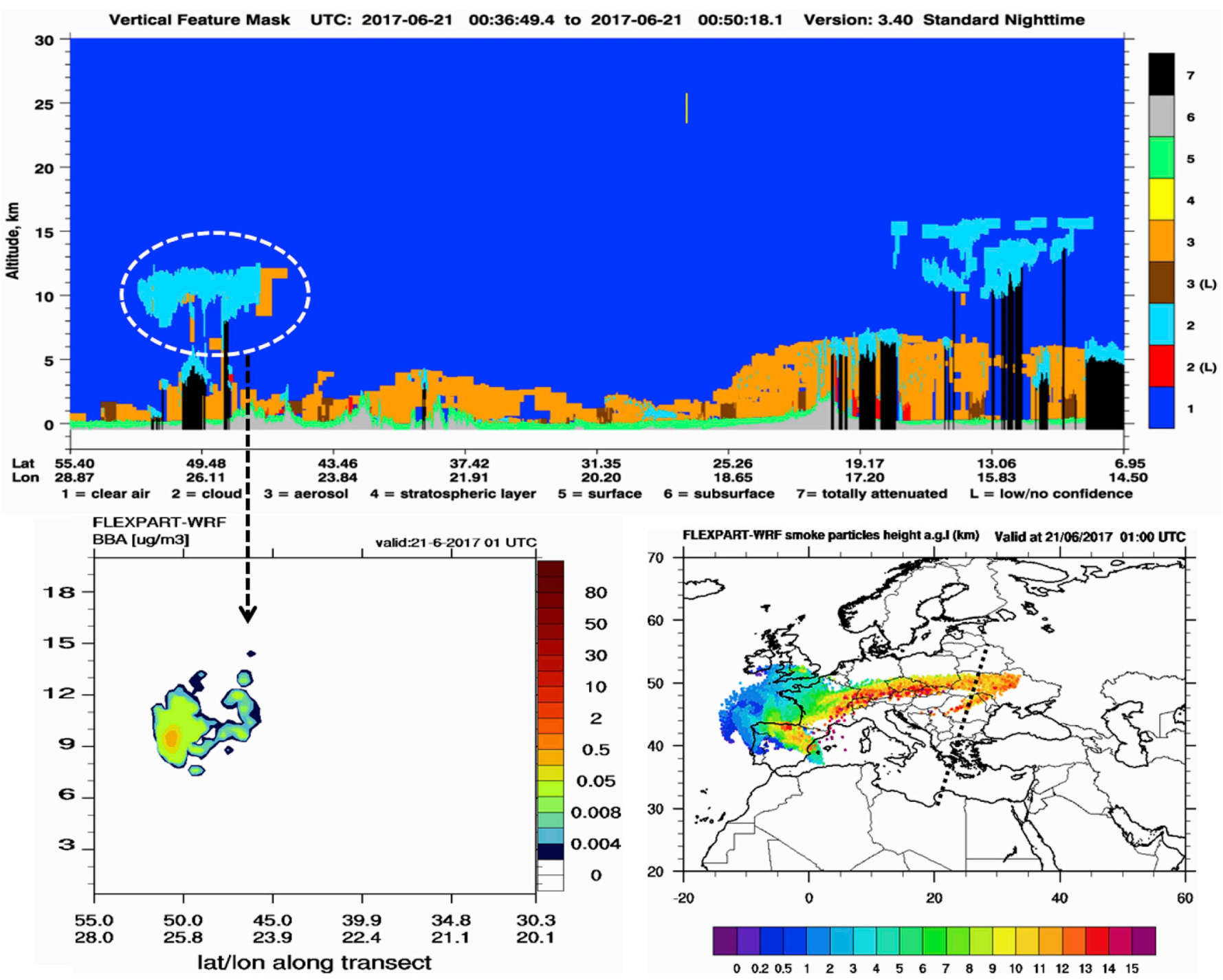

Fig. 8c. i) CALIPSO overpass classification at 00:36-00:50 UTC, 21 June 2017. The dashed white line indicates the observed smoke area and the black arrow shows the corresponding modeled smoke; ii) Collocated vertical cross-section of simulated BBA $\left(\mu \mathrm{g} \mathrm{m}^{-3}\right.$ ) at 01:00 UTC, 21 June 2017; iii) Simulated particles heights (km) at 01:00 UTC, on 21 June 2017. The dashed line indicates the location of CALIPSO overpass.

mass concentration of the elevated BBA layers detected from 22 to 24 June 2017 at this station. The lidar range corrected signal at $1064 \mathrm{~nm}$ is seen in Fig. 7b. The BBA layer is prominent on the first day at about 11.6-12.2 km height, and remained at this height to the end of the day. On the second day aged BBA layers reached the site again, almost 4 days after the emission, and the plume is seen to descend and spread from about 6 to $10 \mathrm{~km}$. Backscatter coefficient and mass concentration profiles at $532 \mathrm{~nm}$, are seen in Fig. 9. The thickness of the smoke layers, the AOD at $532 \mathrm{~nm}$ and maximum (and median) value of BBA mass concentrations are shown in Table 2. As seen previously in Fig. $5 \mathrm{~b}$, the plume arriving at $12 \mathrm{~km}$ is not represented by the model. On the second day the model captures the arrival of BBA though at lower height range. At the end of the second day the model heavily underestimates the concentration of the lower part of the plume. Moreover, the model reveals the existence of a layer at $15 \mathrm{~km}$ which however is not observed by the lidar.

\section{Conclusions and discussion}

This is the first time that smoke layers originating from the west part of Europe and specifically from Portugal are detected at such long distances by EARLINET stations in Europe. The transport path is also justified by satellite retrievals (CALIPSO/CALIOP) and the overall episode suggests a lifetime of 5-7 days for smoke particles in the atmosphere. The model analysis shows that the keys for reproducing the event are: (i) the successful reproduction of convective motions near the sources by WRF model which forced the BBA plumes towards the upper troposphere and (ii) the hourly update of BBA emissions based on geostationary detections that allow a realistic reproduction of the diurnal wildfire strength. The calculation of emission rates and initial plume rise directly from the satellite FRP is found adequate for reproducing the qualitative (spatiotemporal) properties of the BBA layers however the model underestimates the mass concentrations. A first approach to mitigate underestimation could be to adjust the emission factor (C) in Eq. (1) until the model reproduces the observed values. However, this same model configuration has provided reasonable results for a similar environment during the severe 2007 fire events in Greece (Solomos et al., 2015) and since there are no measurements available close to the Portugal wildfires, it is difficult to evaluate the tuning parameter at the source. Furthermore, the long range transported particles are only those that were initially elevated at the higher tropospheric layers due to convective activity. In this context even if the 


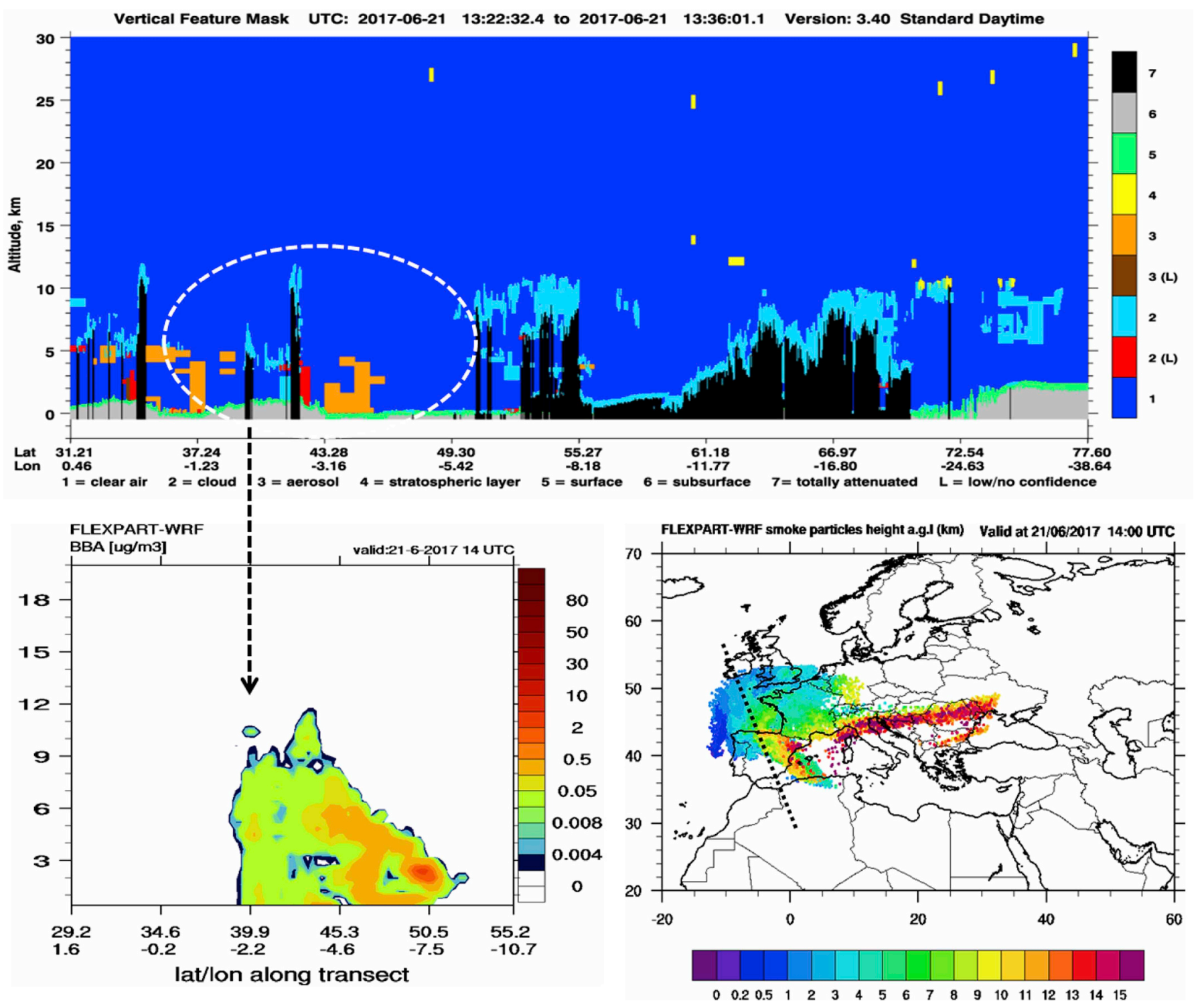

Fig. 8d. i) CALIPSO overpass classification at 13:22-13:36 UTC, 21 June 2017. The dashed white line indicates the observed smoke area and the black arrow shows the corresponding modeled smoke; ii) Collocated vertical cross-section of simulated BBA ( $\mu \mathrm{g} \mathrm{m}^{-3}$ ) at 14:00 UTC, 21 June 2017; iii) Simulated particles heights (km) at 14:00 UTC, on 21 June 2017. The dashed line indicates the location of CALIPSO overpass.

Table 1

Input parameters for the BBA backscatter to mass concentration conversion.

\begin{tabular}{lll}
\hline Parameter & Value & Reference \\
\hline$\rho\left(\mathrm{g} / \mathrm{cm}^{3}\right)$ & 1.35 & Reid et al. (1998) \\
$\mathrm{V} / \tau(\mathrm{m})$ & $0.18 \times 10^{-6}$ & Ansmann et al. (2012) \\
$\mathrm{S}(\mathrm{sr})$ & 70 & $\begin{array}{l}\text { (Giannakaki et al., 2015; Groß et al., 2015; Burton } \\
\text { et al., 2012) }\end{array}$ \\
\hline
\end{tabular}

surface fluxes were correct, a non-accurate representation of vertical motions in the model (i.e. exact place, time and magnitude) or a nonaccurate dilution of the simulated plumes due to the very long range transport could also be the reason for this underestimation.

The main driving force for the uplift of BBA is not the wildfire heat release and the associated change in buoyancy above the wildfire, but the embedment of biomass particles in convective storm cells about $100-200 \mathrm{~km}$ north of the main wildfire areas. The biomass smoke was indeed injected in high tropospheric layers, however it did not penetrate through the stratosphere and this event cannot be classified as a typical pyro-Cb. Moreover, as is evident by both EARLINET and CALIPSO detections, smoke and clouds coexist along the entire transport path. This finding implies the activation of biomass smoke as ice nuclei during glaciation processes. However such processes cannot be explicitly justified by our study, since BBA is a passive tracer in our simulations. As these clouds evaporate, biomass particles are released back to the atmosphere resulting in a secondary particle source at high tropospheric layers. This process needs further research as an indirect transport mechanism that explains the long atmospheric lifetimes and the transport of aged smoke particles at such long distances. 
Table 2

Layer integrated AOD at $532 \mathrm{~nm}$, mass concentration and BBA layer width for the case studies of Leipzig, and Finokalia.

\begin{tabular}{|c|c|c|c|c|c|}
\hline Station & Date/Hour & Layer depth $(\mathrm{km})$ & Lidar AOD & Maximum (median) lidar mass concentration $\left(\mu \mathrm{g} / \mathrm{m}^{3}\right)$ & Model mass concentration $\left(\mu \mathrm{g} / \mathrm{m}^{3}\right)$ \\
\hline Leipzig (a) & $\begin{array}{l}20 / 6 / 2017 \\
22: 25-23: 10\end{array}$ & 4.5 & $0.24 \pm 0.01$ & $22.2(11.7)$ & 1.13 \\
\hline Finokalia (b) & $\begin{array}{l}22 / 6 / 2017 \\
00: 15-02: 30\end{array}$ & 1 & $0.032 \pm 0.001$ & $13, .4(7.9)$ & 0.02 \\
\hline Finokalia (c) & $\begin{array}{l}22 / 6 / 2017 \\
20: 00-00: 00\end{array}$ & 0.6 & $0.008 \pm 0.001$ & $5.1(3.9)$ & 0 \\
\hline Finokalia (d) & $\begin{array}{l}23 / 6 / 2017 \\
00: 00-02: 30\end{array}$ & 0.5 & $0.009 \pm 0.001$ & $7.4(5.3)$ & 0 \\
\hline Finokalia (e) & $\begin{array}{l}23 / 6 / 2017 \\
20: 00-00: 00\end{array}$ & 3.7 & $0.045 \pm 0.004$ & $4.6(2.6)$ & 0.02 \\
\hline
\end{tabular}

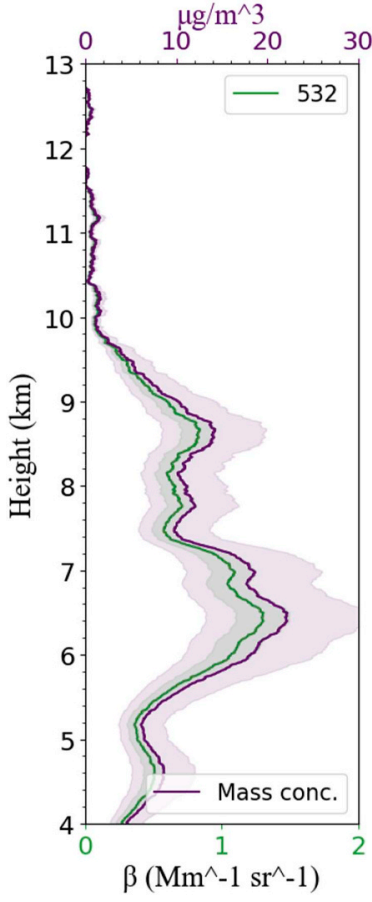

(a)

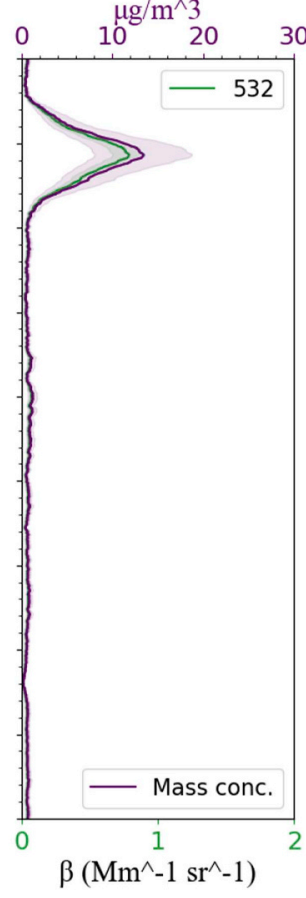

(b)

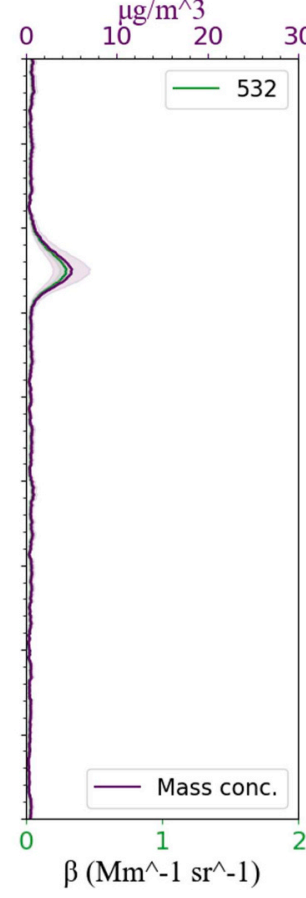

(c)

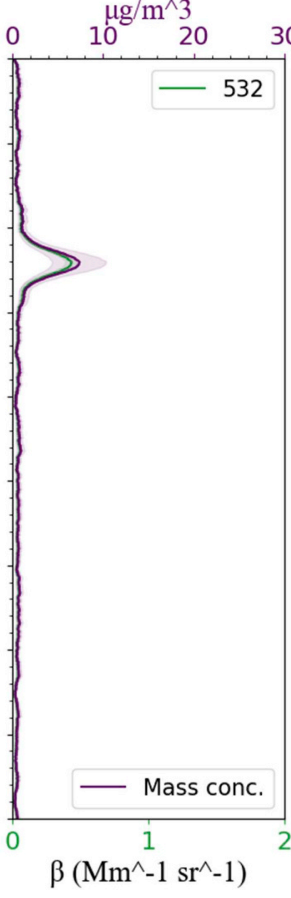

(d)

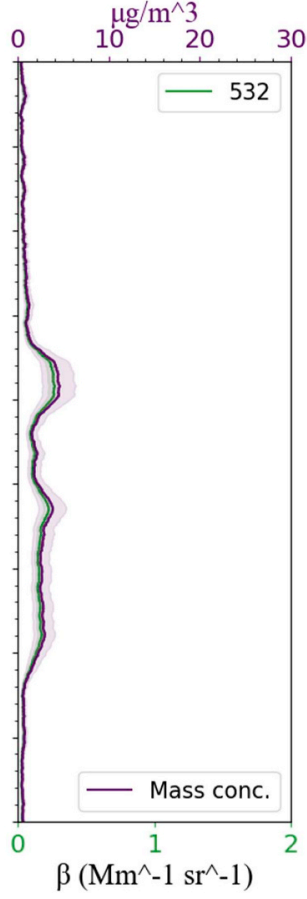

(e)

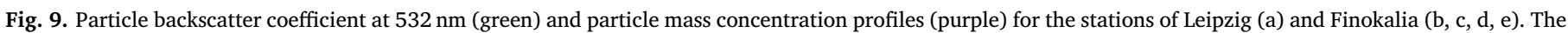

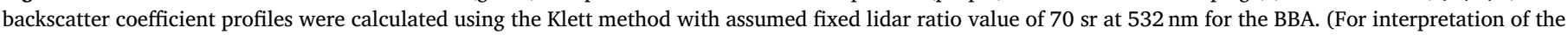
references to color in this figure legend, the reader is referred to the Web version of this article.)

\section{Acknowledgements}

The authors acknowledge support through the following research programmes: BEYOND under grant agreement no. 316210 of the European Union Seventh Framework Programme FP7-REGPOT-20122013-1; ACTRIS-2 under grant agreement no. 654109 of the European Union's Horizon 2020 research and innovation programme; The authors acknowledge EARLINET for providing aerosol lidar profiles available under the World Data Center for Climate (WDCC; the EARLINET publishing group 2000-2010, 2014). CALIPSO data were obtained from the NASA Langley Research Center Atmospheric Science Data Center (https://eosweb.larc.nasa.gov/). SEVIRI FRP data are obtained from the Wildfire Automated Biomass Burning Algorithm (WFABBA) processing system at the University of Wisconsin (http://wfabba.ssec.wisc. edu). We are grateful to AERONET for high-quality measurements, inversions and products (https://aeronet.gsfc.nasa.gov/new_web/ aerosols.html). The authors acknowledge financial support of this work by the project "PANhellenic infrastructure for Atmospheric Composition and climate change" (MIS 5021516) which is implemented under the Action "Reinforcement of the Research and
Innovation Infrastructure", funded by the Operational Programme "Competitiveness, Entrepreneurship and Innovation" (NSRF 2014-2020) and co-financed by Greece and the European Union (European Regional Development Fund) and from the European Research Council (ERC) Consolidator Grant 2016, D-TECT: Does dust Tribo-electrification affect our Climate? H2020-EU.1.1., Excellent Science, Project ID: 725698.

\section{Appendix A. Supplementary data}

Supplementary data to this article can be found online at https:// doi.org/10.1016/j.atmosenv.2019.03.009.

\section{References}

Amiridis, V., Balis, D.S., Giannakaki, E., Stohl, A., Kazadzis, S., Koukouli, M.E., Zanis, P., 2009a. Optical characteristics of biomass burning aerosols over Southeastern Europe determined from UV-Raman lidar measurements. Atmos. Chem. Phys. 9, 2431-2440. https://doi.org/10.5194/acp-9-2431-2009.

Amiridis, V., Giannakaki, E., Balis, D.S., Gerasopoulos, E., Pytharoulis, I., Zanis, P., Kazadzis, S., Melas, D., Zerefos, C., 2010. Smoke injection heights from agricultural 
burning in Eastern Europe as seen by CALIPSO. Atmos. Chem. Phys. 10, 11567-11576. https://doi.org/10.5194/acp-10-11567-2010.

Ansmann, A., Wandinger, U., Riebesell, M., Weitcamp, C., Michaelis, W., 1992. Independent measurement of extinction and backscatter profiles in cirrus clouds by using a combined Raman elastic-backscatter lidar. Appl. Opt. 31, 7113-7131. https://doi.org/10.1364/AO.31.007113.

Ansmann, A., Tesche, M., Seifert, P., Groß, S., Freudenthaler, V., Apituley, A., Wilson, K.M., Serikov, I., Linné, H., Heinold, B., Hiebsch, A., Schell, F., Schmidt, J., Mattis, I., Wandinger, U., Wiegner, M., 2011. Ash and fine-mode particle mass profiles from EARLINET-AERONET observations over central Europe after the eruptions of the Eyjafjallajökull volcano in 2010. J. Geophys. Res. Atmos. 116, D20. https://doi.org/ 10.1029/2010JD015567.

Ansmann, A., Seifert, P., Tesche, M., Wandinger, U., 2012. Profiling of fine and coarse particle mass: case studies of Saharan dust and Eyjafjallajökull/Grimsvötn volcanic plumes. Atmos. Chem. Phys. 12, 9399-9415. https://doi.org/10.5194/acp-12-93992012.

Baars, H., Kanitz, T., Engelmann, R., Althausen, D., Heese, B., Komppula, M., Preißler, J., Tesche, M., Ansmann, A., Wandinger, U., Lim, J.H., Young Ahn, J., Stachlewska, I.S., Amiridis, V., Marinou, E., Seifert, P., Hofer, J., Skupin, A., Schneider, F., Bohlmann, S., Foth, A., Bley, S., Pfüller, A., Giannakaki, E., Lihavainen, H., Viisanen, Y., Kumar Hooda, R., Pereira, S.N., Bortoli, D., Wagner, F., Mattis, I., Janicka, L., Markowicz, K.M., Achtert, P., Artaxo, P., Pauliquevis, T., Souza, R.A.F., Prakesh Sharma, V., Gideon Van Zyl, P., Paul Beukes, J., Sun, J., Rohwer, E.G., Deng, R., Mamouri, R.E., Zamorano, F., 2016. An overview of the first decade of PollyNET: an emerging network of automated Raman-polarization lidars for continuous aerosol profiling. Atmos. Chem. Phys. 16, 5111-5137. https://doi.org/10.5194/acp-16-5111-2016.

Balis, D.S., Amiridis, V., Zerefos, C., Gerasopoulos, E., Andreae, M., Zanis, P., Kazantzidis, A., Kazadzis, S., Papayannis, A., 2003. Raman lidar and sunphotometric measurements of aerosol optical properties over Thessaloniki, Greece during a biomass burning episode. Atmos. Environ. 37, 4529-4538. https://doi.org/10.1016/S13522310(03)00581-8.

Bravo-Aranda, J.A., Belegante, L., Freudenthaler, V., Alados-Arboledas, L., Nicolae, D., Granados-Muñoz, M.J., Guerrero-Rascado, J.L., Amodeo, A., D'Amico, G., Engelmann, R., Pappalardo, G., Kokkalis, P., Mamouri, R., Papayannis, A., NavasGuzmán, F., Olmo, F.J., Wandinger, U., Amato, F., Haeffelin, M., 2016. Assessment of lidar depolarization uncertainty by means of a polarimetric lidar simulator. Atmos. Meas. Tech. 9, 4935-4953. https://doi.org/10.5194/amt-9-4935-2016.

Brioude, J., Arnold, D., Stohl, A., Cassiani, M., Morton, D., Seibert, P., Angevine, W., Evan, S., Dingwell, A., Fast, J.D., Easter, R.C., Pisso, I., Burkhart, J., Wotawa, G., 2013. The Lagrangian particle dispersion model FLEXPART-WRF version 3.1. Geosci. Model Dev. (GMD) 6, 1889-1904. https://doi.org/10.5194/gmd-6-1889-2013.

Burton, S.P., Ferrare, R.A., Hostetler, C.A., Hair, J.W., Rogers, R.R., Obland, M.D., Butler, C.F., Cook, A.L., Harper, D.B., D.B., Froyd, K.D., 2012. Aerosol classification using airborne High Spectral Resolution Lidar measurements - methodology and examples. Atmos. Meas. Tech. 5, 73-98. https://doi.org/10.5194/amt-5-73-2012, 2012.

Engelmann, R., Kanitz, T., Baars, H., Heese, B., Althausen, D., Skupin, A., Wandinger, U., Komppula, M., Stachlewska, I.S., Amiridis, V., Marinou, E., Mattis, I., Linné, H., Ansmann, A., 2016. The automated multiwavelength Raman polarization and watervapor lidar Polly ${ }^{\mathrm{XT}}$ : the neXT generation. Atmos. Meas. Tech. 9, 1767-1784. https:// doi.org/10.5194/amt-9-1767-2016.

Fernald, F.G., 1984. Analysis of atmospheric lidar observations: some comments. Appl. Opt. 23, 652-653. https://doi.org/10.1364/AO.23.000652.

Flamant, C., Pelon, J., Flamant, P.H., Durand, P., 1997. Lidar determination of the entrainment zone thickness at the top of the unstable marine atmospheric boundary layer. Bound. Lay. Meteorol. 83, 247-284. https://doi.org/10.1023/ a:1000258318944.

Freeborn, P.H., Wooster, M.J., Hao, W.M., Ryan, C.A., Nordgren, B.L., Baker, S.P., Ichoku, C., 2008. Relationships between energy release, fuel mass loss, and trace gas and aerosol emissions during laboratory biomass fires. J. Geophys. Res. Atmos. 113. https://doi.org/10.1029/2007JD008679.

Freudenthaler, V., 2016. About the effects of polarising optics on lidar signals and the $\Delta 90$ calibration. Atmos. Meas. Tech. 9, 4181-4255. https://doi.org/10.5194/amt-9-41812016.

Fromm, M.D., Servranckx, R., 2003. Transport of forest fire smoke above the tropopause by supercell convection. Geophys. Res. Lett. 30, 1542. https://doi.org/10.1029/ 2002GL016820.

Fromm, M., Lindsey, D.T., Servranckx, R., Yue, G., Trickl, T., Sica, R., Doucet, P., GodinBeekmann, S., 2010. The untold story of pyrocumulonimbus. Bull. Am. Meteorol. Soc. 91, 1193-1209. https://doi.org/10.1175/2010BAMS3004.1.

Giannakaki, E., Balis, D.S., Amiridis, V., Zerefos, C., 2010. Optical properties of different aerosol types: seven years of combined Raman-elastic backscatter lidar measurements in Thessaloniki, Greece. Atmos. Meas. Tech. 3, 569-578. https://doi.org/10.5194/ amt-3-569-2010.

Giannakaki, E., Pfüller, A., Korhonen, K., Mielonen, T., Laakso, L., Vakkari, V., Baars, H., Engelmann, R., Beukes, J.P., Van Zyl, P.G., Josipovic, M., Tiitta, P., Chiloane, K., Piketh, S., Lihavainen, H., Lehtinen, K.E.J., Komppula, M., 2015. One year of Raman lidar observations of free-tropospheric aerosol layers over South Africa. Atmos. Chem. Phys. 15, 5429-5442. https://doi.org/10.5194/acp-15-5429-2015.

Groß, S., Freudenthaler, V., Wirth, M., Weinzierl, B., 2015. Towards an aerosol classification scheme for future EarthCARE lidar observations and implications for research needs. Atmos. Sci. Lett. 16, 77-82. https://doi.org/10.1002/asl2.524.

Holben, B.N., Eck, T.F., Slutsker, I., Tanré, D., Buis, J.P., Setzer, A., Vermote, E., Reagan, J.A., Kaufman, Y.J., Nakajima, T., Lavenu, F., Jankowiak, I., Smirnov, A., 1998. AERONET - a federated instrument network and data archive for aerosol characterization. Remote Sens. Environ. 66, 1-16. https://doi.org/10.1016/S0034-
4257(98)00031-5.

Hosseini, S., Li, Q., Cocker, D., Weise, D., Miller, A., Shrivastava, M., Miller, J.W., Mahalingam, S., Princevac, M., Jung, H., 2010. Particle size distributions from laboratory-scale biomass fires using fast response instruments. Atmos. Chem. Phys. 10, 8065-8076. https://doi.org/10.5194/acp-10-8065-2010.

Ichoku, C., Ellison, L., 2014. Global top-down smoke-aerosol emissions estimation using satellite fire radiative power measurements. Atmos. Chem. Phys. 14, 6643-6667. https://doi.org/10.5194/acp-14-6643-2014.

Ichoku, C., Kaufman, Y.J., 2005. A method to derive smoke emission rates from MODIS fire radiative energy measurements. IEEE Trans. Geosci. Remote Sens. 43, 2636-2649. https://doi.org/10.1109/TGRS.2005.857328.

Klett, J.D., 1981. Stable analytical inversion solution for processing lidar returns. Appl. Opt. 20, 211-220. https://doi.org/10.1364/AO.20.000211.

Mattis, I., Ansmann, A., Müller, D., Wandinger, U., Althausen, D., 2004. Multilayer aerosol observations with dual-wavelength Raman lidar in the framework of EARLINET. J. Geophys. Res. Atmos. 109, D13203 1-D1320315. https://doi.org/10. 1029/2004JD004600.

Mattis, I., Muller, D., Ansmann, A., Wandinger, U., Preissler, J., Seifert, P., Tesche, M., 2008. Ten years of multiwavelength Raman lidar observations of free-tropospheric aerosol layers over central Europe: geometrical properties and annual cycle. J. Geophys. Res. Atmos. 113, D20202. https://doi.org/10.1029/2007jd009636.

Müller, D., Mattis, I., Wandinger, U., Ansmann, A., Althausen, D., Stohl, A., 2005. Raman lidar observations of aged Siberian and Canadian forest fire smoke in the free troposphere over Germany in 2003: microphysical particle characterization. J. Geophys. Res. Atmos. 110, D17201. https://doi.org/10.1029/2004jd005756.

Müller, D., Ansmann, A., Mattis, I., Tesche, M., Wandinger, U., Althausen, D., Pisani, G., 2007. Aerosol-type-dependent lidar ratios observed with Raman lidar. J. Geophys. Res. Atmos. 112, D16202. https://doi.org/10.1029/2006jd008292.

Omar, A.H., Winker, D.M., Kittaka, C., Vaughan, M.A., Liu, Z., Hu, Y., Trepte, C.R., Rogers, R.R., Ferrare, R.A., Lee, K.P., Kuehn, R.E., Hostetler, C.A., 2009. The CALIPSO automated aerosol classification and lidar ratio selection algorithm. J. Atmos. Ocean. Technol. 26, 1994-2014. https://doi.org/10.1175/ 2009JTECHA1231.1.

Pappalardo, G., Wandinger, U., Mona, L., Hiebsch, A., Mattis, I., Amodeo, A., Ansmann, A., Seifert, P., Linné, H., Apituley, A., Arboledas, L.A., Balis, D., Chaikovsky, A., D'Amico, G., De Tomasi, F., Freudenthaler, V., Giannakaki, E., Giunta, A., Grigorov, I., Iarlori, M., Madonna, F., Mamouri, R.E., Nasti, L., Papayannis, A., Pietruczuk, A., Pujadas, M., Rizi, V., Rocadenbosch, F., Russo, F., Schnell, F., Spinelli, N., Wang, X., Wiegner, M., 2010. EARLINET correlative measurements for CALIPSO: first intercomparison results. J. Geophys. Res. Atmos. 115, D00H19. https://doi.org/10.1029/ 2009JD012147.

Reid, J.S., Hobbs, P.V., Ferek, R.J., Blake, D.R., Martins, J.V., Dunlap, M.R., Liousse, C., 1998. Physical, chemical, and optical properties of regional hazes dominated by smoke in Brazil. J. Geophys. Res. Atmos. 103, 32059-32080 art. no. 98JD00458.

Rosenfeld, D., Fromm, M., Trentmann, J., Luderer, G., Andreae, M.O., Servranckx, R., 2007. The Chisholm firestorm: observed microstructure, precipitation and lightning activity of a pyro-cumulonimbus. Atmos. Chem. Phys. 7, 645-659. https://doi.org/ 10.5194/acp-7-645-2007.

Skamarock, W.C., Klemp, J.B., 2008. A time-split nonhydrostatic atmospheric model for weather research and forecasting applications. J. Comp. Phys. 227, 3465-3485. https://doi.org/10.1016/j.jcp.2007.01.037.

Solomos, S., Amiridis, V., Zanis, P., Gerasopoulos, E., Sofiou, F.I., Herekakis, T., Brioude, J., Stohl, A., Kahn, R.A., Kontoes, C., 2015. Smoke dispersion modeling over complex terrain using high resolution meteorological data and satellite observations - the FireHub platform. Atmos. Environ. 119, 348-361. https://doi.org/10.1016/j. atmosenv.2015.08.066.

Tesche, M., Ansmann, A., Müller, D., Althausen, D., Engelmann, R., Freudenthaler, V., Groß, S., 2009. Vertically resolved separation of dust and smoke over Cape Verde using multiwavelength Raman and polarization lidars during Saharan Mineral Dust Experiment 2008. J. Geophys. Res. Atmos. 114https://doi.org/10.1029/ 2009JD011862. art. no. D13202.

Tesche, M., Müller, D., Gross, S., Ansmann, A., Althausen, D., Freudenthaler, V., Weinzierl, B., Veira, A., Petzold, A., 2011a. Optical and microphysical properties of smoke over Cape Verde inferred from multiwavelength lidar measurements. Tellus, Ser. B 63, 677-694. https://doi.org/10.1111/j.1600-0889.2011.00549.x.

Tesche, M., Gross, S., Ansmann, A., Müller, D., Althausen, D., Freudenthaler, V., Esselborn, M., 2011b. Profiling of Saharan dust and biomass-burning smoke with multiwavelength polarization Raman lidar at Cape Verde. Tellus, Ser. B 63, 649-676. https://doi.org/10.1111/j.1600-0889.2011. 00548.x.

Vakkari, V., Beukes, J.P., Dal Maso, M., Aurela, M., Josipovic, M., van Zyl, P.G., 2018. Major secondary aerosol formation in southern African open biomass burning plumes. Nat. Geosci. 11, 580-583. https://doi.org/10.1038/s41561-018-0170-0.

Winker, D.M., Vaughan, M.A., Omar, A., Hu, Y., Powell, K.A., K.A., Liu, Z., Hunt, W.H., Young, S.A., 2009. Overview of the CALIPSO mission and CALIOP data processing algorithms. J. Atmos. Ocean. Technol. 26, 2310-2323. https://doi.org/10.1175/ 2009JTECHA1281.1.

Wooster, M.J., Roberts, G., Perry, G.L.W., Kaufman, Y.J., 2005. Retrieval of biomass combustion rates and totals from fire radiative power observations: FRP derivation and calibration relationships between biomass consumption and fire radiative energy release. J. Geophys. Res. Atmos. 110, 1-24. https://doi.org/10.1029/ 2005JD006018.

Zhang, X., Kondragunta, S., Ram, J., Schmidt, C., Hung, H.C., 2012. Near-real-time global biomass burning emissions product from geostationary satellite constellation. J. Geophys. Res. Atmos. 117. https://doi.org/10.1029/2012JD017459. 